\title{
Same Same but Different? Gender, sex work, and respectability politics in the MyRedBook and Rentboy closures
}

\author{
Samantha Majic
}

\begin{abstract}
Among the many policies implemented to eradicate trafficking in the sex industry, US government agencies have targeted online platforms that market and facilitate sex work. In this paper, I consider two instances of this activity: the Federal Bureau of Investigation's 2014 raid and subsequent closing of MyRedbook.com, and the Department of Homeland Security's 2015 raid and closing of Rentboy.com. Drawing from a qualitative-interpretive analysis of the media coverage of these raids, I show that the responses to them emphasised how the sites' closures increased both men's and women's economic vulnerability, but the similarities largely ended there. Instead, I argue broadly that public responses to these events reflected and reinforced gendered notions of women's vulnerability and men's agency in the sex industry. While these responses may seem unsurprising, they are also potentially productive, calling into question the limits of respectability politics and signalling new solidarities in the struggle for sex worker rights.
\end{abstract}

Keywords: sex work, human trafficking, technology, gender, LGBT, respectability politics, media, neoliberalism, online platforms

Please cite this article as: S Majic, 'Same Same but Different? Gender, sex work, and respectability politics in the MyRedBook and Rentboy closures', AntiTrafficking Review, issue 14, 2020, pp. 82-98, https://doi.org/10.14197/ atr.201220146

This is an open-access article distributed under the terms of the Creative Commons Attribution License (CC-BY). Under the CC-BY license, the public is free to share, adapt, and make commercial use of the work. Users must always give proper attribution to the authors and the Anti-Trafficking Review. 
When law enforcement came for MyRedBook for sex work ads—and before that, Craigslist and Backpage-there was criticism, but not like this. ... Where the attacks on Rentboy were understood by activists and organizations as attacks on the LGBTQ community, attacks on MyRedBook were met with comparative silence from feminists, along with cursory reporting and little editorial support from mainstream media.

Melissa Gira Grant ${ }^{1}$

The sex industry has long been at the forefront of technological change and adaptation: an extensive body of research indicates that both women and men increasingly arrange commercial sexual exchanges online using various websites and mobile technologies. ${ }^{2}$ Yet as the sex industry has modernised, concerns about trafficking in the industry have intensified, especially since 2000, when the US federal government passed the Trafficking Victims Protection Act (TVPA). Among the many policies and procedures implemented to eradicate human trafficking, government agencies have endeavoured to end the availability of commercial sexual services by targeting online platforms, namely websites that operate as intermediaries between sex workers and clients to market and facilitate sex work. ${ }^{3}$

In this article I consider two recent instances of this activity: the Federal Bureau of Investigation's (FBI) 2014 raid and subsequent closing of MyRedbook.com (MyRedbook), and the Department of Homeland Security's (DHS) 2015 raid and closing of Rentboy.com (Rentboy). MyRedbook was founded in 1999 in California, by Eric 'Red' Omuro and Annemarie Lanoce, and like Rentboy, it hosted ads, but from women escorts and massage parlours targeting male clients. The site was notoriously low-tech — posting an ad was free, but one could pay a fee to display their ad more prominently on the site. Clients could browse the site for free, but they had to pay to access escort reviews, enhanced search options, and 'VIP forums'. MyRedbook also offered a chat room for sex workers and clients, where each group could share information with the other about services, risks, etc. Founded by Jeffrey Hurant, Rentboy opened for business in 1997 as an 'ad listing' service where male escorts paid a monthly fee to place ads so that

$1 \quad$ M Gira Grant, 'How Sex Workers' Rights Made the Mainstream', Rewire News, 11 September 2015, retrieved 7 December 2019, https://rewire.news/article/2015/09/11/ sex-workers-rights-made-mainstream.

2 S Cunningham and T D Kendall, 'Prostitution 2.0: The changing face of sex work', Journal of Urban Economics, vol. 69, no. 3, 2011, pp. 273-87, https://doi.org/10.1016/j. jue.2010.12.001; I Vanwesenbeeck, 'Prostitution Push and Pull: Male and female perspectives', J Sex Res, vol. 50, no. 1, 2013, pp. 11-16, https://doi.org/10.1080/00 224499.2012.696285.

3 H Rand, 'Challenging the Invisibility of Sex Work in Digital Labour Politics', Feminist Review, vol. 123, no. 1, 2019, pp. 40-55, https://doi.org/10.1177/0141778919879749. 
clients could contact them directly. Additionally, the site offered a message board where clients posted escort reviews. Although comprehensive data about the site's use is not available, there is evidence that it was popular: in 2009, Rentboy hosted 40,000 escort profiles in dozens of countries ${ }^{4}$ and, at the time of its seizure, had 500,000 unique visitors per day. ${ }^{5}$

Even as MyRedbook and Rentboy were similar sites, Gira Grant's epigraph above indicates that their respective raids generated very different responses, thereby raising questions relevant to this special issue regarding the consequences of restricting technologies in the service of anti-trafficking efforts. In this paper, I consider the discursive consequences of these varied responses. Drawing from a qualitative-interpretive analysis of the media coverage of these raids, I show that the responses to them emphasised how they would increase both men's and women's economic vulnerability, but the similarities largely ended there. Instead, I argue that public responses to these events reflected and reinforced gendered notions of women's vulnerability and men's agency in the sex industry. But while these responses may seem unsurprising, they are also potentially productive, raising questions about the limits of respectability politics and signalling new solidarities in the struggle for sex worker rights.

\section{Technology and Sex Work}

Technological developments such as the invention of the motor vehicle and the telephone have long shifted the structure of the sex industry, but among these, the internet has had the most significant impact. ${ }^{6}$ Through it, the creation of online platforms such as Rentboy and MyRedbook (among many others) have afforded sex workers more flexibility and choice in how they work, and have also expanded opportunities for advertising and booking clients independently. Furthermore, internet technologies have also enhanced sex workers' safety by shifting work indoors and providing them with tools to screen their clients through background checks and consultations with other sex workers. Clients also may use these technologies to review and research sex workers. ${ }^{7}$ Furthermore, these

4 S Weinstein, 'The Queer Issue: The rise of Rentboys', Village Voice, 24 June 2009, retrieved 12 February 2020, https://www.villagevoice.com/2009/06/24/the-queerissue-the-rise-of-rentboys.

5 J Vincent, 'Seven arrested over multimillion-dollar “internet brothel” Rentboy.com', The Verge, 26 August 2015, https://www.theverge.com/2015/8/26/9209623/ rentboy-arrests-escort-service.

6 Cunningham and Kendall, p. 273; C MacPhail, J Scott, and V Minichiello, 'Technology, Normalisation and Male Sex Work', Cult Health Sex, vol. 17, no. 4, 2015, pp. 483-95, https://doi.org/10.1080/13691058.2014.951396.

7 Cunningham and Kendall, p. 277. 
developments have enhanced sex workers' solidarity and security by increasing peer contact and opportunities to reach out to, network, and organise with other sex workers. ${ }^{8}$

Of course, internet technologies are not accessible to everyone and they also come with risks. Internet access is costly, and thus affluent sex workers are more able to access and benefit from online technologies than their less affluent peers. ${ }^{9}$ Alongside and linked to class disadvantages, as Helen Rand summarises, there is growing evidence of racial stratification in online sex work, as those with white bodies are often more privileged and profitable, particularly in emerging subsectors of the industry like webcam modelling. ${ }^{10}$ Additionally, the internet has expanded law enforcement's capacity to investigate and arrest persons engaging in prostitution. ${ }^{11}$ But among these risks, human trafficking has raised the most alarm-a so-called 'pink scare'. According to anti-prostitution advocate Melissa Farley and her colleagues, 'Adapted by traffickers, pimps, and pornographers, the global reach of the internet has facilitated sex buyers' access to prostituted women and children, thereby increasing sex trafficking. ${ }^{12}$

Although such claims have never been systematically verified, online technologies have 'become the new battleground spaces upon which longstanding disagreements about sex work, human trafficking, and the sexual exploitation of youth are enacted'..$^{13}$ These battles are most apparent in public and political discussions about platforms like Craigslist and Backpage, which have been 'cited by attorneys general, journalists, and anti-trafficking advocates as key facilitators of trafficking online'..$^{14}$ But even as these platforms raise concerns about human trafficking,

8 R Weitzer, 'Researching Sex Work in the Twenty-First Century', Contemporary Sociology, vol.42, no. 5, 2013, pp. 713-22, https://doi.org/10.1177/0094306113499536b.

9 For example, in 2015, the Bureau of Statistics found that the mean annual cost of cellular phone service was USD 1,023 per household, up from USD 963 in 2014. See https://www.bls.gov/cex/2015/combined/age.pdf

10 Rand, p. 8.

11 S Cunningham and T D Kendall, 'Prostitution, Technology, and the Law: New data and directions', in L R Cohen and J D Wright (eds.), Research Handbooks in Law and Economics, Edward Elgar, Cheltenham, UK and Northampton, MA, 2011, pp. 221-70.

12 M Farley, K Franzblau, and A Kennedy, 'Online Prostitution and Trafficking', Albany Law Review, vol. 77, no. 3, 2014, pp. 1039-94.

13 M Thakor and d boyd, 'Networked Trafficking: Reflections on technology and the anti-trafficking movement', Dialectical Anthropology, vol. 37, no. 2, 2013, pp. 277-90, p. 279, https://doi.org/10.1007/s10624-012-9286-6.

14 J L Musto and d boyd, 'The Trafficking-Technology Nexus', Social Politics: International Studies in Gender, State \& Society, vol. 21, no. 3, 2014, pp. 461-83, p. 466, https://doi.org/10.1093/sp/jxu018. 
they also may disrupt it by helping law enforcement investigate trafficking cases with face recognition software, predictive analytics, and mapping techniques to identify traffickers. As well, connective technologies allow anti-trafficking advocates to mobilise their networks, spread anti-trafficking messages, and fundraise. And companies like Google and Yahoo (among others) see antitrafficking efforts as making good philanthropic and business sense. In December 2011, for example, Google donated USD 11.5 million to help anti-trafficking organisations support new technology initiatives. ${ }^{15}$

While existing scholarship has considered technology's possibilities and limits for facilitating and combatting coerced or consensual sex work, it has not considered the MyRedbook and Rentboy raids and how, if at all, the responses to these raids reflected and reinforced certain gender and other political ideologies. Examining the different responses to these raids thus provides an intriguing case for understanding the intersection of anti-trafficking efforts and the struggle for sex worker rights in the internet age.

\section{Methods}

Following Deva Woodly's work on political persuasion, I analysed media coverage of MyRedbook and Rentboy as a means for gauging public discourse about their raids and closures. ${ }^{16}$ Here I defined and counted as media coverage any related pieces in newspapers, newswires, news networks (e.g. abc.com), and online news sources (e.g. Huffington Post), which my research assistants, B Stone and Lauren Moton, found through the databases EBSCOHost, Gannet Newsstand (ProQuest), Google News, and Lexis Nexis by using the terms 'MyRedbook' and 'Rentboy'. They included any and all articles that discussed the sites published before and after the raids to provide a benchmark for how and in what context these sites were discussed before they were shut down. In total, they collected 217 articles: 68 articles about MyRedbook and 149 articles about Rentboy.

Next, I organised these articles in Atlas.ti for coding, which I understand as primarily an interpretive act. ${ }^{17}$ To this end, I first grouped the articles for each site into two categories_-before and after the raid-and coded each article to

15 Ibid., pp. 463-475; see also H Dixon, 'Human Trafficking and the Internet* (*and Other Technologies, Too)', The Judges' Journal, vol. 52, no. 1, 2013, pp. 36-39.

16 D Woodly, 'The Importance of Public Meaning for Political Persuasion', Perspectives on Politics, vol. 16, issue 1, 2018, pp. 22-35, https://doi.org/10.1017/ S1537592717003127.

17 J Saldaña, The Coding Manual for Qualitative Researchers, 3rd Edition, SAGE, Los Angeles \& London, 2016. 
capture its year, outlet, and the centrality of the site to the article (e.g. main focus [headline] of the article) and whether it contained photos. Second, I conducted 'descriptive' or 'topic' coding by assigning 'a word or short phrase that symbolically assigns a summative, salient, essence capturing, and/or evocative attribute' to each article. ${ }^{18}$ Altogether, the articles fell into the following topical categories: the sites' raids and related events (such as the owners' sentencing), adult sex work, youth sex work, LGBT rights, online sex, sex scandals, and trafficking in the sex industry.

Third, I conducted in-depth, qualitative coding for each article to capture how public discourse about the raids characterised sex work, sex trafficking and sex workers. Here I understood discourse as the interactive process of conveying ideologies through both images and verbal text. ${ }^{19}$ In particular, I was interested in the gendered ideologies conveyed through the articles, and to discern these, I employed a critical feminist approach that considered how 'frequently taken-forgranted gendered assumptions and hegemonic power relations are discursively produced, sustained, negotiated, and challenged in different contexts and communities'.$^{20}$ Working within an intersectional paradigm, I attended to how discussions of the websites and sex work/ers in the media considered multiple categories of social identity, including race, class, sexuality, etc. ${ }^{21}$

My discursive codes came from the literature regarding technology and sex work, noted previously and, following Woodly, from inductively reading the news articles to draw codes from them that captured portions of text related to various topics. ${ }^{22}$ These codes are presented in Table 1 below.

18 Ibid., p. 4

19 G Rose, Visual Methodologies: An introduction to researching with visual materials, 3rd Edition, SAGE, London \& Thousand Oaks, CA, 2012.

20 M Lazar, 'Feminist Critical Discourse Analysis: Articulating a feminist discursive practice', Critical Discourse Studies, vol. 4, no. 2, 2007, pp. 141-64, p. 142, https:// doi.org/10.1080/17405900701464816.

21 A M Hancock, 'When Multiplication Doesn't Equal Quick Addition: Examining intersectionality as a research paradigm', Perspectives on Politics, vol. 5, no. 1, 2007, pp. 63-79, https://doi.org/10.1017/S1537592707070065.

22 Woodly, p. 25. 


\begin{tabular}{|c|c|}
\hline Topic (Code Group) & Codes \\
\hline Descriptions/pictures of sex workers featured in articles & $\begin{array}{l}\text { Race (white, black, Asian, Latinx, none specified), age } \\
\text { (child, teen, adult), gender (men, women, transgender) }\end{array}$ \\
\hline Motivations for engaging in sex work & $\begin{array}{l}\text { Third-party coercion } \\
\text { Economic } \\
\text { Psychopathology } \\
\text { Sexual exploration/enjoyment } \\
\text { Sexual victimisation as a child } \\
\text { Other }\end{array}$ \\
\hline General characterisation of sex work & $\begin{array}{l}\text { As victimisation } \\
\text { As work } \\
\text { As sexual freedom (should be left alone) }\end{array}$ \\
\hline Internet sex work - Advantages & $\begin{array}{l}\text { For clients - opportunity (e.g. screening and reviewing } \\
\text { sex workers) } \\
\text { For sex workers - opportunity (e.g. advertising, screening } \\
\text { clients) } \\
\text { For law enforcement (e.g. to search for traffickers) } \\
\text { For corporations and non-profits (e.g. to help anti- } \\
\text { trafficking efforts) } \\
\text { Safety (shifts sex workers off streets) }\end{array}$ \\
\hline Internet sex work - Disadvantages & $\begin{array}{l}\text { Expands sex industry } \\
\text { General dangers (of sex work) } \\
\text { Facilitates human trafficking }\end{array}$ \\
\hline Other internet and other sex work related issues & $\begin{array}{l}\text { LGBT rights } \\
\text { Amnesty International } \\
\text { Decriminalisation of prostitution } \\
\text { Legal issues }\end{array}$ \\
\hline
\end{tabular}

Table 1: Codes for MyRedbook and Rentboy articles.

In analysing the material, if I found, for example, that articles about MyRedbook were mainly coded regarding how the website facilitates human trafficking and characterised sex work as victimisation, I would interpret that as a public response promoting a more traditional gender ideology about women sex workers as victims.

\section{Findings}

\section{Raids in Context}

On 24 June 2014, the FBI arrested Omuro and Lanoce on charges of facilitating prostitution through MyRedbook, and on multiple counts of money laundering. And the next year, on 25 August 2015, the DHS and members of the New York Police Department raided Rentboy's offices in New York, arresting Hurant and six others on his staff on charges of conspiring to violate the Travel Act by promoting prostitution. Even as both sites provided nearly identical services to sex workers and their clients, the Rentboy raid and its aftermath received much more coverage (120 articles) than did the progression of the MyRedbook case (56 articles). Both of these appeared mainly in regional papers (the NY Daily News 
provided the most coverage of the Rentboy case details, while the San Francisco Chronicle did the same for MyRedbook). Furthermore, a wider range of groups responded to Rentboy's closure. With the exception of the Electronic Frontier Foundation, only sex worker rights groups spoke against MyRedbook's closing, most notably the Sex Workers Outreach Project (SWOP), 'a national social justice network dedicated to the fundamental human rights of people involved in the sex trade and their communities', and other Bay Area-based sex worker rights groups such as the Erotic Service Providers Union. ${ }^{23}$ In contrast, both sex worker rights groups and LGBT/civil rights groups such as Lambda Legal and the GLBTQ Legal Advocates \& Defenders responded to the Rentboy raid. The remainder of this section considers what these responses to the raids, as captured through media coverage, discursively indicate about sex work, trafficking, and sex workers.

\section{Same Same but Different?}

The consensus in existing research is that economic considerations motivate a person's engagement in sex work, ${ }^{24}$ and the public response across groups and articles emphasised that both sites' closures would increase men and women's economic vulnerabilities. At least twenty of 56 articles about the MyRedbook raid and its aftermath highlighted women's economic motivations for sex work, such as an article in The Atlantic, where a woman sex worker explained that 'Most people, I think, go into sex work because it fits their current needs. Maybe they can't work a 9-to-5 job because they're in school, or they have young children so they need a really flexible job. That's why I started doing sex work. I was in school, and I had a child, and I needed something that I could work nights. ${ }^{25}$ Given this, at least 30 articles indicated that MyRedbook's closure would reduce women sex workers' economic opportunities by, for example, limiting their capacity to advertise their services. ${ }^{26}$ Similarly, at least 49 articles in response to the Rentboy raid emphasised men's economic vulnerability such as an op-ed in The Guardian, which noted, 'The federal prosecution of third-party advertisers like Rentboy and myRedBook ... will destroy an informal economy that includes many of us whom are undocumented, or don't have a degree or other means to surmount the high barriers of entry to an occupation in the formal economy. ${ }^{.27}$ And these economic losses would be particularly acute for gay and transgender men, as indicated in

23 See http://www.new.swopusa.org.

24 Venwesenbeeck, p. 12.

25 C Hall, 'Is One of the Most-Cited Statistics About Sex Work Wrong?', The Atlantic, 6 September 2014.

26 See, for example, S Q, 'Red Alert: The feds shut down an escort site', SF Weekly, 9 July 2014.

27 Anonymous, 'Rentboy Wasn't My "Brothel". It was a tool to stay alive in this economy of violence', The Guardian, 1 September 2015. 
at least 29 of the 120 post-raid articles. As the New York Times editorial board wrote, 'In New York, where homeless shelters for gay and transgender youths have lengthy waiting lists, sex work can mean the difference between sleeping on a bed and sleeping on the street. For others, it is a way to afford a degree. The Rentboy. com bust may spook clients and sex workers for a while, but it would be naïve to think it will do much more. ${ }^{28}$

However, the similarities in the responses to these raids largely ended here. Articles about the MyRedbook closure largely provided much more traditional gendered discourse about women's victimisation in sex work, with all 56 post-raid articles discussing to some degree how the site's closure would increase risks and decrease the safety for women sex workers. In fact, numerous articles noted that the site helped women protect themselves, stating here that its closure would send more sex workers back to the streets, where they are at a heightened risk for violence from clients and the police. For example, as one article noted, 'The elimination of online advertising would send many sex workers back to the dark ages of street work. To avoid attracting the attention of law enforcement, workers would jump too quickly into the cars of customers they haven't screened, with no time to negotiate payment or services before finding themselves in a small space equipped with child-safety locks in the company of a strange man. ${ }^{29}$ Furthermore, the site's closure would diminish sex workers' capacity to screen clients and determine if they are safe. As an op-ed in San Francisco Weekly pointed out, 'MyRedbook was not just an advertising platform, but also a resource for sex workers to screen potential clients. Without resources for adequate screening and safety procedures, I fear my community will be forced to make riskier choices in order to feed their families and pay their bills. ${ }^{30}$

This emphasis on women sex workers' potential victimisation was particularly apparent in the eleven articles that discussed the relationship between internet sex work and trafficking, featuring here quotations or perspectives that raised the spectre of the 'pink scare'. For example, an article in the San Francisco Chronicle quoted an Assistant District Attorney who stated, 'In my experience prosecuting these types of cases, [MyRedbook] is associated with the setting up of dates that often involve women who are being exploited or are victims of human trafficking ... I view it as a positive development that the federal authorities were able to take such strong action against it. ${ }^{31}$ But numerous articles also indicated that

28 Editorial Board, 'Homeland Security's Peculiar Prosecution of Rentboy', New York Times, 28 August 2015, p. A18.

29 T Burns, 'The War on Sex Workers Escalates with FBI Shutdown of Myredbook', Vice, 17 July 2014.

30 S Q.

31 V Ho and H Aleaziz, 'Bay Area Prostitution Site Myredbook.Com Seized by Feds', San Francisco Chronicle, 25 June 2014. 
closing MyRedbook would not help to fight trafficking and may instead increase sex workers' risks for it. As one article stated, '[MyRedbook] has previously been used as a law enforcement resource for investigators targeting pimps and human traffickers. Officers have posed as clients or offering services in order to arrange meetings and make arrests. ${ }^{32}$ This led some to wonder, 'How are the cops going to find trafficking victims now that there's nowhere for them to advertise?'33

In contrast, the public response to the Rentboy raid emphasised men's (noneconomic) victimisation to a much lesser extent than it did for women. At least 61 post-raid articles noted these issues, such as a New York Times editorial that said the shutdown was not justified, as it was a company that provided sex workers with a safer alternative to street walking or relying on pimps'. ${ }^{34}$ As performer Andy Boyce stated in an article, 'By taking away a consensual platform for sex workers to conduct business, many are forced to resort to more unsafe methods of obtaining clients. ${ }^{35}$ Yet even as media coverage raised these issues, only two articles about Rentboy noted human trafficking in relation to male sex work, and just eight raised the issue more generally. In fact, unlike the articles about MyRedbook, the individuals quoted and/or the authors emphasised that trafficking was not an issue for Rentboy users. As advocates claimed in an article in New York Magazine, 'the site had nothing to do with human trafficking and doubt[ed] whether there are any victims in this criminal activity ${ }^{36}{ }^{36}$ Consequently, there were no discussions in the Rentboy articles about how the site would help protect male sex workers by, for example, helping the police find traffickers.

Instead, the public response to Rentboy's closure highlighted men's agency in sex work, as indicated by the fact that 117 post-raid articles emphasised that the site's raid and closure compromised gay men's sexual pleasures and freedoms. As one male sex worker noted, sex work is preferable to a 9-to-5 job because of the "freedom and flexibility" it provides ... Plus it's something I like to do anyway'. ${ }^{37}$ For many, then, the closure of Rentboy was seen as a 'war on sex' that would

32 KCRA, 'MyRedBook Seized by FBI, IRS; Alleged Owners Indicted', KCRA News, 26 June 2014.

33 Burns.

34 Editorial Board, p. A18.

35 J M Nichols, 'The Unexpected and Powerful Story of a Sex Worker Affected by the Rentboy Raid', Huffington Post, 28 July 2015.

36 T Murphy, 'What Did Busting Rentboy.Com Do to the Hustler Economy? 6 Rent boys tell all', New York Magazine, 25 September 2015.

37 N Tempey, 'After Rentboy Crackdown, Angry Sex Worker Condemns "Growing Moral Panic"', Gothamist, 26 August 2015. 
compromise these freedoms, ${ }^{38}$ especially since Rentboy was able to operate as 'an unabashed celebration of gay sex and intimacy ... something of an institution in the gay world since it was launched in 1997'. ${ }^{39}$ Since 1998 it sponsored a float in New York City's annual gay pride parade, and it founded the annual International Escort Awards (the 'Hookies') in 2006. It also hosted the 'Hustlaball', a sex cabaret and dance party, in London, Berlin, and Las Vegas to raise money for charities such as Gay Men's Health Crisis. Since the site had existed for so long and so publicly, with little known harm to anyone in particular, the raid seemed of another era: as Justin Bond, a performer and activist told the New York Times, 'To many in our community this feels like a throwback to when the police raided gay bars in the '50s and '60s. ${ }^{30}$ Therefore, at least seven articles about the Rentboy raid included some version of the phrase 'Why now?' For example, an article in the Gothamist was titled 'Why Is Homeland Security Going After Male Escort Website Rentboy After 18 Years?' and numerous articles variously speculated about the reasons for Rentboy's raid, ranging from claims that it was a 'political act' to a possible expression and exercise of homophobia on the part of government agencies. ${ }^{41}$ There were no similar 'why now' articles for the MyRedbook raid.

\section{Respectability Politics and Solidarity in the Struggle for Rights}

These different responses to the raids are unsurprising to a degree: they reflect how male sex workers have, somewhat paradoxically, benefitted from being almost completely ignored by social service providers and administrative bodies, and from the media and popular culture's reinforcement of archetypes of agentic male buyers and vulnerable women sellers. Since male sex workers have largely been unburdened by associations with and assumptions about trafficking and victimisation in the sex industry and thus not subject to related service and policy interventions, they have not had to prove that they are agentic individuals who

38 DE Nahmod, 'Rentboy.Com CEO, Employees Arrested in New York', Bay Area Reporter, 26 August 2015.

39 N DiDomizio, 'A Huge Gay Escort Website Was Shut Down. Here's Why We Need to Care', Mic, 26 August 2015.

40 S Clifford, 'Raid of Rentboy, an Escort Website, Angers Gay Activists', New York Times, 26 August 2015, p. A20.

41 Ibid.; see also S Weinstein, 'Why Did the Feds Bust Rentboy?', Vice, 4 September 2015, and M E O'Hara, 'DHS, DOJ Silent on Congressman's Questions About Anti-LGBT Agenda in Rentboy Case', The Daily Dot, 9 March 2016. 
can speak in their own interests as women sex workers have struggled to do. ${ }^{42}$ The different responses to these raids therefore reflect longstanding gender ideologies about men and women's capacities to engage and exercise agency in sex work.

Yet at the same time, these different responses are potentially productive for illuminating the limits and possibilities of LGBT and sex worker rights organising. Since the 1970 s, 'according to that conventional narrative, lesbians and gay men have slowly but surely gained ever-greater access to full citizenship in many spheres of life' including marriage and access to the military, among others. ${ }^{43}$ The mainstream LGBT movement made these gains, in large part, through respectability politics. Coined by Evelyn Brooks Higginbotham to describe black women's efforts to resist and dissolve white Americans' negative stereotypes about them, respectability politics involves enacting the rhetorical and behavioural norms modelled in straight white men, based on the belief that equal treatment will follow. ${ }^{44}$ Among the many groups to deploy these politics are those in the mainstream LGBT movement like GLAD and Lambda Legal, as indicated by their devotion of considerable efforts and resources to issues that advance the interests of their predominantly white and affluent (read: 'respectable') constituents. By focusing on issues like marriage equality and access to the military, critics contend that this respectability strategy has benefitted 'those whose sexual lives have fit comfortably within widely accepted canons of propriety, privacy,

42 R Andrijasevic and N Mai, 'Editorial: Trafficking (in) Representations: Understanding the recurring appeal of victimhood and slavery in neoliberal times', Anti-Trafficking Review, issue 7, 2016, pp. 1-10, https://doi.org/10.14197/atr.20121771; D S Bimbi, 'Male Prostitution: Pathology, paradigms and progress in research', J Homosex, vol. 53, no. 1-2, 2007, pp. 7-35, https://doi.org/10.1300/J082v53n01_02; JP Dennis, 'Women Are Victims, Men Make Choices: The invisibility of men and boys in the global sex trade', Gender Issues, vol. 25, no. 1, 2008, pp. 11-25, https://doi. org/10.1007/s12147-008-9051-y; V Minichiello, J S Victor and D Callander, 'A New Public Health Context to Understand Male Sex Work', BMC Public Health, vol. 15, no. 282, 2015, pp. 1-11, https://doi.org/10.1186/s12889-015-1498-7; A Schloenhardt, P Astill-Torchia, and J Jolly, 'Be Careful What You Pay For: Awareness raising on trafficking in persons', Washington University Global Studies Law Review, vol. 11, issue 2, 2012, pp. 415-35.

43 S De Orio, 'The Invention of Bad Gay Sex: Texas and the creation of a criminal underclass of gay people', Journal of the History of Sexuality, vol. 26, no. 1, 2017, pp. 53-87, p. 53, https://doi.org/10.7560/JHS26103.

44 E Brooks Higginbotham, Righteous Discontent: The women's movement in the black Baptist Church, 1880-1920, Harvard University Press, Cambridge, 1993. See also: A I Khan, 'Michael Sam, Jackie Robinson, and the Politics of Respectability', Communication \& Sport, vol. 5, no. 3, 2015, pp. 331-51, https://doi.org/10.1177/ 2167479515616407; and M Lamont Hill, 'Thank You, Black Twitter - State violence and pedagogies of resistance', Urban Education, vol. 53, no. 2, 2018, pp. 286-302, https://doi.org/10.1177/0042085917747124. 
domesticity, and coupledom ...' ${ }^{\text {'45 }}$

The response to the Rentboy raid indicates the limits of respectability politics in the pursuit of LGBT rights, particularly for members of racial minority groups. Scholars have written that respectability politics' neoliberal emphasis on propriety and individual uplift ignores social and structural inequalities, which are not changed by ascending class status. ${ }^{46}$ As Jane Ward's work on LGBT activist organisations demonstrates, these neoliberal claims to participation-that individuals must change themselves first-has often led the mainstream LGBT movement to discard or leave behind its members who do not fit market needs. ${ }^{47}$ In this way, even as many members of the LGBT community have benefitted from the movement's gains, it is not news that many others remain extremely disadvantaged by, among other things, poverty, employment discrimination, harassment and violence, and this socio-economic marginalisation is compounded for LGBT persons of colour. ${ }^{48}$ Therefore, it is entirely unsurprising that some LGBT persons may engage in sex work for economic survival. As one article about the Rentboy raid noted, 'They are the people left behind by the advances in LGBT equality, and they have often paid the price for our community's overall success, in the form of backlash, violence, or government action like the Rentboy bust. ${ }^{\text {'49 }}$

The precarity of LGBT rights gains, particularly through the frame of white respectability politics, was especially apparent when Rentboy was raided and shut down. In the media coverage, numerous articles featured pictures of Hurant-a white, affluent man-while others featured pictures of scantily clad white men in clubs or on computer screens posing as escorts. In a highly visible and public way, these pictures indicated that sex work is not solely the purview of those on the racialised margins of the gay community, nor are these individuals the only

45 De Orio, p. 54.

46 F C Harris, 'The Rise of Respectability Politics', Dissent, vol. 61, no. 1, 2014, pp. 33-37.

47 E J Ward, Respectably Queer: Diversity culture in LGBT activist organizations, Vanderbilt University Press, Nashville, 2008.

48 E A Edelman, “This Area Has Been Declared a Prostitution Free Zone”: Discursive formations of space, the state, and trans "sex worker" bodies', J Homosex, vol. 58, no. 6-7, 2011, pp. 848-64, https://doi.org/10.1080/00918369.2011.581928; A Hollibaugh and M Weiss, 'Queer Precarity and the Myth of Gay Affluence', New Labor Forum, vol. 24, no. 3, 2015, pp. 18-27, https://doi.org/10.1177/ 1095796015599414; J Jones et al., 'The Experiences of African American Male Commercial Sex Workers at-Risk for HIV: Accessing outreach services', Journal of Gay \& Lesbian Social Services, vol. 21, no. 2-3, 2009, pp. 282-93, https://doi. org/10.1080/10538720902772238.

49 J Michaelson, 'Will the Rentboy.Com Bust Be the "Stonewall" of Sex Work?' The Daily Beast, 26 August 2015. 
persons at risk for arrest and punishment. Now that this punishment has turned to websites like Rentboy, it was 'a harsh reminder that even male privilege does not protect you from the vice squad'. ${ }^{50}$ More specifically, not even white male privilege provides this protection.

But in signalling the fragility of the gains made for LGBT people through respectability politics, the response to the Rentboy raid also drew attention to the struggle for sex workers' rights and indicated the potential for new solidarities. In 2015, just two weeks before the Rentboy raid, Amnesty International resolved to develop and adopt a policy on the decriminalisation of prostitution. ${ }^{51}$ To many advocates, this was not a controversial proposal: a vast body of evidence indicates that criminalising and stigmatising sex work has done little to keep sex workers safe and healthy. ${ }^{52}$ Yet, responses to Amnesty's decision were deeply gendered: while sex worker rights groups cheered, numerous feminists openly opposed Amnesty's proposal, particularly for women sex workers. Opponents claimed decriminalisation would promote sex trafficking and other exploitation of women..$^{53}$ However, advocates for and against Amnesty's proposal were largely silent about its potential impact on male sex workers, which arguably left open a discursive gap. When Rentboy was raided and advocates responded, they cited the Amnesty decision to support their opposition to the site's raid and closure. In fact, at least 30 post-raid articles about Rentboy variously mentioned the Amnesty decision's importance for and relevance to (male) sex workers' opposition to the raid. ${ }^{54}$

In effect, even though LGBT rights groups were largely silent in the debates leading up to Amnesty's decision, ${ }^{55}$ they used it to support sex worker and LGBT rights after the Rentboy raid. In fact, 61 post-raid articles about Rentboy mentioned sex worker rights and the need to decriminalise prostitutionsomething that was not discussed in response to the MyRedbook raid. As an article in Mic noted, 'The raid ultimately adds to the case for decriminalizing sex work. Earlier this month, the sex worker rights movement took a huge step forward when the human rights organization Amnesty International recommended that sex work be decriminalized, as current laws criminalizing prostitution put sex

50 M Ludwig, 'Beyond Rentboy: Will the LGBT movement really fight for sex worker rights?', Truthout, 1 September 2015.

51 Murphy.

52 See, for a comprehensive example, research published in The Lancet's series 'HIV and Sex Workers', 23 July 2014, retrieved 7 January 2020, https://www.thelancet.com /series/hiv-and-sex-workers.

53 Coalition Against Trafficking in Women, Letter to Amnesty International: Opposition to Decriminalization, 2015.

54 See, for example, Editorial Board, p. A18.

55 Ludwig. 
workers' lives at risk. Yet with the shuttering of Rentboy, many sex workers and gay rights activists are concerned that both movements are taking one step back. ...In other words, there is still much work to be done to de-stigmatize both sex work and gay sex. ${ }^{.56}$

And so, as others went on to claim, 'This thoroughly unnecessary bust should be the impetus to legalize and regulate consensual sex work. It should become the "Stonewall" of sex workers, the moment in which they and their allies say: Enough. ${ }^{.57}$ In line with this sentiment, the LGBT rights movement has taken steps to support sex workers. In March 2019, the International Lesbian, Gay, Bisexual, Trans and Intersex Association (ILGA World), the world federation of over 1,600 national and local LGBT non-government organisations, called for the decriminalisation of consensual adult sex work..$^{58}$ While it is too early to tell whether the LGBT and sex worker rights movements will join forces in a sustained manner and to what effect, the Rentboy raid has certainly put sex worker rights on the mainstream LGBT movement's radar.

\section{Conclusion}

In closing, I will turn briefly to this special issue's theme of speculative futures, particularly regarding the role of technology and sex work. In theory, in the broader context of growing economic inequality, platforms like MyRedbook and Rentboy offered many individuals - especially those on the margins of societyan opportunity to engage in sex work independently, flexibly, and off the streets. In so doing, these platforms represented the 'future' of work under neoliberal late capitalism; however, they also created what Mark Lamont Hill terms a 'digital counter-public', ${ }^{59}$ where members of a marginalised and stigmatised group could both arrange sexual exchanges with their clients and communicate with each other to enhance their safety and foster solidarity. MyRedbook and Rentboy indicate how digital technologies may offer a means for resisting hegemonic norms, including those regarding gendered and sexual behaviour. ${ }^{60}$

56 DiDomizio.

57 Michaelson.

58 ILGA World, 'LGBTI organisations from across the world call for decriminalisation of sex work', 23 March 2019, retrieved 26 November 2019, https://ilga.org/ sex-work-lgbti-organisations-call-for-decriminalisation.

59 Lamont Hill, p. 286.

60 M Pitcan, A E Mikaela, and d boyd, 'Performing a Vanilla Self: Respectability politics, social class, and the digital world', Journal of Computer-Mediated Communication, vol. 23, no. 3, 2018, pp. 163-79, https://doi.org/10.1093/jcmc/zmy008. 
Yet the US federal government's raids on and closures of MyRedbook and Rentboy also indicate the limits of technological advancement for furthering sex workers' and other marginalised groups' economic wellbeing and social inclusion more broadly. The 'pink scare' has increased the state's surveillance of online platforms where individuals arrange commercial sexual exchanges. As a result, while platforms like MyRedbook and Rentboy may have fostered sexual and economic freedom for men and women, they could not exist independently from and resist the dominant discourses and state practices regarding sex work and trafficking. Certainly, their closures may direct men and women sex workers to other platforms, but one may reasonably speculate that it is only a matter of time before these are subject to MyRedbook and Rentboy's fate.

Taken together, the findings in this article indicate directions for future research and offer important political insights. Regarding the former, given law enforcement's power to access technology in pursuit of anti-trafficking efforts (for example, they may now demand that sex workers show them their phones to expose clients $\left.{ }^{61}\right)$, researchers must consider the gendered and racialised outcomes of these law enforcement efforts, and how men and women sex workers respond to them. Regarding the latter, the findings in this article signal the importance of formulating new solidarities and political strategies that eschew neoliberal respectability politics. The Rentboy raid was, arguably, a paradoxical outgrowth of the mainstream LGBT movement's efforts and success with these politics. As critics have argued, by focusing on marriage, access to the military, and criminal punishment as means to combat violence against gay people, the movement has adopted a carceral focus that has led to a 'queer investment in punishment ${ }^{62}$ that has 'work[ed] to authorise, invoke and legitimise a particular criminological vision and promise for the future' ${ }^{63}$ To reshape this vision of the future, sex workers, the LGBT community, and their allies must work with their intersecting concerns in mind and consider both the opportunities and constraints that technological developments offer in the pursuit of gender, racial, and sexual justice.

Samantha Majic, PhD, is an Associate Professor of political science at John Jay College of Criminal Justice, City University of New York. Her research considers sex work, civic engagement, gender politics, and celebrities, and has appeared in numerous political science and gender studies journals. She is also the author of

61 Musto and boyd, p. 471.

62 J L Mogul, A J Ritchie, and K Whitlock. Queer (in)Justice: The criminalization of LGBT people in the United States, Beacon Press, Boston, 2011.

63 S Lamble, 'Queer Necropolitics and the Expanding Carceral State: Interrogating sexual investments in punishment', Law and Critique, vol. 24, no. 3, 2013, pp. 229-53, p. 232, https://doi.org/10.1007/s10978-013-9125-1. 
three books: Sex Work Politics: From protest to service provision (University of Pennsylvania Press, 2014), Negotiating Sex Work: Unintended consequences of policy and activism (University of Minnesota Press, 2014, co-edited with Carisa Showden), and Youth Who Trade Sex in the US: Agency, intersectionality, and vulnerability (Temple University Press, 2018, co-authored with Carisa Showden). Email: smajic@jjay.cuny.edu 